Copyright (C) 2019 by Academic Publishing House Researcher

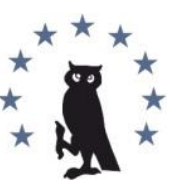

Published in the Russian Federation

European Researcher. Series A

Has been issued since 2010.

E-ISSN 2224-0136

2019, 10(1): 66-74

DOI: 10.13187/er.2019.1.66

www.erjournal.ru

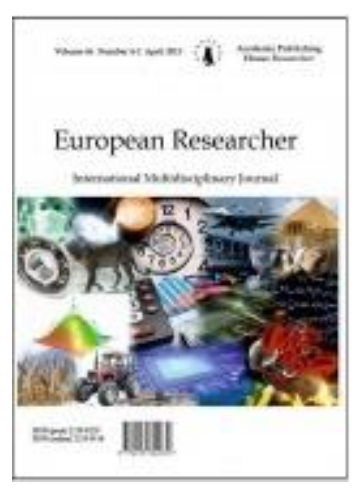

\title{
Law on Enterprises at Using Agricultural Land in Vietnam Nowadays: Reality and Petition for Some Scopes to be changed
}

\author{
Luan Nguyen Thanh a, * \\ ${ }^{a}$ Hanoi Law University, The Socialist Republic of Vietnam
}

\begin{abstract}
This research focuses on analyzing scopes of Land Law 2013 about enterprises in using Vietnamese agricultural land nowadays with following contents: land using forms; incentives and support of The State for enterprises in assessing and using agricultural land. Besides, it also researches and clarifies the limitations raised from the reality of implementing these scopes and then recommends to complete Land Law 2013 in the way which will make the more advantageous condition for enterprises in accessing, using agricultural land with a view to boosting the great development of Vietnamese agriculture in these days.

Keywords: enterprise, agricultural land, preference, support, Land Law.

\section{Introduction}

Since the execution of "Doi Moi" (12/1986) which introduced reforms intended to facilitate the transition from a centrally planned economy to form of market socialism officially termed "Socialist-oriented market economy", enterprises have been able to be established and be active in Vietnamese economy. During that time until now, the number and scale of enterprises are more and more developing in a speedy way and they have a remarkable contribution to the impressive development of the Vietnamese economy. However, a happening reality that is the cooperation of enterprise into the agricultural field is very limited in both number and scale of activity, this has made Vietnamese agriculture which already has much potential but has not yet achieved an overall and strong development in a modern way. Being aware of the importance of enterprises towards the development of agriculture, Vietnamese lawmakers had built the incentive and supportive policy aiming to attract enterprises to invest in this economic field. The most noticeable things are the stipulations about incentives and supports in accessing and using agricultural land an indispensable input factor to agricultural production. Nevertheless, through the reality of execution, the scopes of Land Law 2013 have revealed the weakness that needs of modification. These issues will be fully expounded in this article.
\end{abstract}

\section{Document and study method}

2.1. This research is executed basing on currently stipulation of Vietnamese law for enterprises in using agricultural land and some previous stipulations. Simultaneously, it is also executed by referring published researches such as: "Report on review of agriculture and food of OECD: Agricultural policy in Vietnam" (OECD, 2015), "Provision of agricultural land law in

\footnotetext{
${ }^{*}$ Corresponding author

E-mail addresses: thanhluanbdbp@gmail.com (L. Nguyen Thanh)
} 
Vietnam - reality and petition for changes" (Luan Nguyen Thanh, 2018a), "Law in recovery of agricultural land to develop socio-economic for national and public interest of Vietnam nowadays: reality and petition for changes" (Luan Nguyen Thanh, 2018b) ...

2.2. It's completed by simultaneously using different research techniques such as analysis, general, dialectical materialism, interpretation, comparison, history, ... to dissect and comment on those problems relating to enterprises in using agricultural land in Vietnam.

\section{Discussion}

According to the stipulation in Article 3.27 Land Law 2013, enterprise means an economic organization, a cooperative or another economic organization as prescribed by the civil law. According to the stipulation in Article 4.7 Law on Enterprises 2014, enterprise means an organization that has its own name, assets, office and is registered in accordance with law to do business. Enterprises include of these types: (i) Limited liability companies include single-member limited liability companies and multi-member limited liability companies, (ii) joint stock company, (iii) partnership, (vi) private company.

In general, the role of enterprise in the development of Vietnamese economy during this time is extremely huge, which is shown as: "Currently, enterprises contribute most to the development scale of economy, accounts for 60\% GDP of overall economy...” (General Statistics Office, 2018).

With superior advantage for capital, labor, management experience, enthusiasm and sensitivity for the movement of the market economy as well as the ability to apply science and technology into production, the numerous participation of enterprises in agricultural production is the premise to develop agriculture in a comprehensive and modern way. Hence, an enterprise is encouraged to join in agricultural production with many preferences, capital support, market, science, and technology, human resources... Agricultural land, in particular, enterprises have a preference, support in accessing and using agricultural land. These preference and support are not only stipulated in Land Law but are also stipulated directly in one personal Decree of The State about encouraging enterprises to invest in agriculture, specifically in Decree No. 61/2010/ND-CP at first, next to Decree No. 210/2013/ND-CP and now is Decree No. 57/2018/ND-CP.

Primarily, according to stipulation in Article 133.1 and Article 169 Land Law 2013, to become an agricultural land user (subject of agricultural land use right), economic organization must have agricultural land use rights by these forms: the State leasing agricultural land, acquiring agricultural land use rights through receipt of transfer of agricultural land use rights, receipt of donation of land use rights, receipt of contribution of land use rights as capital (except the case prescribed in Article 191.2 of Land Law 2013 which is economic organizations may not acquire the rights to use paddy land, protection forest land or special-use forest land from households or individuals, except the case of change in land use purpose in accordance with the land use master plan and plans approved by competent state agencies). Compared to household and individual in becoming subject of agricultural land use rights, enterprise has fewer opportunities because apart from the types which have agricultural land use rights like enterprise, household and individual still have land leasing from the State and their agricultural land use rights are recognized with the agricultural land in use which is still stable and have no conflict.

To give enterprises a better advantage in accessing agricultural land, the stipulation in Article 110.1 a Land Law 2013 and Article 16.1 Decree No 118/2015/ND-CP about guiding Law on Investment 2014 wrote that enterprises using the land for agricultural production means that the State lease the land for them without through auctions of land use rights. Besides, enterprises in using agricultural land have these following incentives and support:

Firstly, in exemption or reduction of land using fee.

According to stipulation in Article 5 Decree No. 57/2018/ND-CP, enterprises which have agricultural projects (especially investment incentives, investment incentives and encouragement on investment) with the land is allocated by the State or by change of land use purpose to make house for workers as stipulated in Article 55 Land Law 2013 about allocating land with land use levy, will be exempted from the transfer of land use purpose fee for the land area that will be converted to housing construction for workers working in the project; will be exempted from land use fees for that land area after being converted.

Secondly, exemption or reduction of fee in land rent or water surface rent. 
According to the provisions of Article 6 of Decree No. 57/2018/ND-CP and regulations on the list of sectors under preferential career and field which are stipulated in Appendix II, regulations on geographical areas which are eligible for investment incentives in Appendix II, issued together with Decree No. 118/2015/ND-CP, enterprises with agricultural projects are entitled to exemption or reduction of land rent and water surface rent of the State if they belong to the following cases:

Firstly, agricultural projects, especially investment incentives, are projects in the list of specially investment incentives sectors such as: planting, tending, nurturing, protecting and developing forests; cultivating, processing and preserving agricultural, forestry and aquatic products; production, multiplication and hybridization of plant varieties, animal breeds, forest tree seeds and aquatic breeds; salt production, salt exploitation and refining ..., which are implemented in areas with particularly difficult socio-economic conditions such as: Bac Kan, Cao Bang, Ha Giang, Lai Chau, Dak Nong, Kon Tum... , then the projects will be exempted from land and water surface rent since the day the State leases land and water surface.

Secondly, agricultural projects with investment incentives, are projects on the list of investment incentives industries for raising, planting, harvesting and processing pharmaceutical materials; protection and preservation of genetic resources and rare and endemic medicinal species; producing and refining food for cattle, poultry and aquatic products; techniques for cultivation, husbandry, aquaculture, crop and livestock protection; building and developing concentrated material areas in service of processing industries ...; which are in areas with difficult socio-economic conditions such as Kim Boi, Ky Son, Luong Son, Lac Thuy and Tan Lac districts , Cao Phong, Lac Son, Yen Thuy in Hoa Binh province; Phong Dien, Quang Dien, Phu Loc, Phu Vang districts and Huong Tra town of Thua Thien Hue province; The districts of Dong Phu, Chon Thanh, Hon Quan, Binh Long and Phuoc Long towns of Binh Phuoc province ... shall enjoy land rental and/or water surface rental as calculated according to preferential land prices announced by the Provincial-level People's Committee and fixed for at least 05 years. At the same time, the enterprise which has an investment incentives project in agriculture will be exempted from land and water surface rent for the first 15 years since the State leased land, water surface and has $50 \%$ off of land rent and water surface rent for the next 7 years.

Thirdly, agricultural projects to encourage investment are projects on the list of especially investment incentives sectors, investment incentives, implemented in areas which are not in the difficult socio-economic conditions and the extremely difficult socio-economic conditions, are entitled to the land rental and/or water surface rental as calculated according to preferential land prices announced by the Provincial-level People's Committee and fixed for at least o5 years. At the same time, the enterprise will be exempted from land and water surface rent for the first 11 years since the State leased land, water surface and has $50 \%$ off of land rent and water surface rent for the next 5 years.

Besides, enterprises with these agricultural projects also have leased land by the State to build houses for workers of the project, non-agricultural production land (land for construction of factories, warehouses, land-use yards, roads, and trees); even with the land permitted to be converted into land categories prescribed in this Clause to serve such projects, shall be exempt from land rent.

Especially with small and medium-sized enterprises which have just been established, they will be exempted from land and water surface rent from the State for the first 5 years since the project will be completed and run into operation and have $50 \%$ off of land rent and water surface rent in the next 10 years. Small and medium enterprises in the agricultural sector as stipulated in Article 6 of Decree No. 39/2018/ND-CP include:

Firstly, a microenterprise has an annual average of 10 employers or fewer who have made contributions to social insurance and total annual revenue is not more than VND 3 billion or total capital is not more than VND 3 billion.

Secondly, a small enterprise has an annual average of 100 employers or fewer who have made contributions to social insurance and total annual revenue is not more than VND 50 billion or total capital is not more than VND 20 billion.

Thirdly, a medium-sized enterprise has an annual average of 200 employers or fewer who have made contributions to social insurance and total annual revenue is not more than VND 200 billion or total capital is not more than VND 100 billion. 
In addition, subsidies for land consolidation: According to Article 7 stipulated in Article 7 Decree number 57/2018/ND-CP, enterprises which execute agricultural projects will be supported with subsidies for land consolidation as follows:

An enterprise that has an agriculture project eligible for special investment incentives and leases or sub-leases land and/or water surface from households or individuals for implementing such project may receive a subsidy from the Government, equivalent to $20 \%$ of the land rental and/or water surface rental for the first five years from the date on which the project officially starts its operation. The land rental and/or water surface rental shall be calculated according to preferential land prices announced by the Provincial-level People's Committee and fixed for at least 05 years.

An enterprise that has an agriculture project (which is eligible for either special investment incentives or investment incentives, or is an encouraged agriculture project) and receives land contributed as capital by a household or individual for establishment of a material zone shall be eligible to receive a subsidy which is VND 50 million/ha but shall not exceed VND 10 billion/project from the Government, and is not required to convert the form of use of such land area into leased land.

If an enterprise that consolidates land under both forms specified in Clause 1 and Clause 2 of this Article, it shall receive all of the subsidies granted according to these clauses from the Government.

During the lease period of an enterprise investing in agriculture and rural development sector, the Government shall not adjust the land use plan so as to avoid adverse influence on the project, except the case where the Government must appropriate the land for national defense or security purpose, socio-economic development in the national or public interest and special case where the land use plan must be adjusted as follows: There are adjustments to the strategies for socio-economic development, national defense, and security or master plan for development of socio-economic regions and such adjustments result in change of land use structure; natural disasters or wars result in changes in the land use purposes, structure, locations, and area; there are adjustments in the land use master plan of the immediate superior level which affect the land use master plan of the concerned level; there are adjustments to local administrative boundaries; adjustments to a land use plan are only conducted when there are adjustments in the land use master plan or there are changes in the ability to implement the land use plan.

Despite this preference and support, the participation of enterprises in agricultural production in Vietnam is still very limited in reality, which means the subject of agricultural land use rights - enterprise has the limit in number, specifically: "Until 01/01/2017, in total of 518,000 enterprises which are working and being collected data through total investigation,... The sector of agriculture, forestry and aquaculture has the fewest number of enterprises with 4.942, increased $27 \%$ compared to the year 2012. In this sector, the number of on-going enterprises is 4.447 in the year 2017, increased $34,5 \%$ compared to 2012, averagely in gradation 2012-2017, this region only increased 6,1 \% each year" (General Statistics Office, 2017).

For the foreign-invested enterprise, it is still an enterprise in nature. However, this subject does not belong to the sector of economic organization as stipulated in Article 3.27 Land Law 2013 but it is stipulated particularly. According to scope in Article 5.7 Land Law 2013, foreign-invested enterprises include of $100 \%$ foreign-invested enterprises, joint-venture enterprises, Vietnamese enterprises in which foreign investors purchase shares, merge or acquire in accordance with investment law. To become the subjects of agricultural land use rights as stipulated in Article 133.1 and Article 169.1.h.e Land Law 2013 as well as enterprises becomes the subjects of agricultural land use rights, they must acquire land use rights through land lease by the State and especially joint ventures must acquire land use rights through receipt of contribution of land use rights as capital.

Foreign-invested enterprise also gets preference and support in accessing and using agricultural land to execute investment project for agriculture as a domestic enterprise. However, in fact, the investment participation of foreign-invested enterprises in agricultural production is very limited, specifically: "According to the Foreign Investment Department (Ministry of Planning and Investment), as of February 2018, total foreign direct investment (FDI) in agriculture was 3.5 million USD with 514 projects. In comparison with the total accumulated investment in the agricultural sector, this capital only accounts for about $1 \%$ " (Tam Thanh, 2018). At the same time, the area of agricultural land used by this subject is very small with 23,965 hectares (0.08 \%) out of 
a total of 27,284,906 hectares of agricultural land nationwide (Ministry of Natural Resources and Environment, 2017).

Hence, from the above analysis, it can be affirmed that although enterprises are regulated by the law for incentives and supports to develop, enterprises have not taken advantage of these opportunities to develop in both quantity and quality in agriculture.

The main reason of this situation is that agriculture in Vietnam is still an economic sector that has not attracted investment enterprises because it contains many risks with many uncertainties and losses for agricultural producers caused by many reasons such as weather, natural disasters, epidemics, prices, breeds ... (Nghi Nguyen Quoc, 2014). In addition, the profitability ratio of the agricultural sector in comparison with other industries such as construction and services in Vietnam is low so it does not create an attraction for enterprises to invest, specifically: industry and construction generate profits that dominate the entire business sector ... while the agriculture, forestry and fishery sector in 2017 only generates VND 4.96 trillion of profit, accounts for o, $6 \%$, increases $2.9 \%$ "(General Statistics Office, 2018).

Subsequently, the provisions of the Land Law 2013 as well as incentives and supports still hinder economic organizations, which have not yet attracted the investment economic organizations into agricultural production from accessing and using agricultural land. This is reflected in the following contents:

Firstly, Land Law 2013 makes it difficult for enterprises to access agricultural land and accumulate agricultural land.

In addition to being leased agricultural land by the State, point b, Clause 1 of Land Law allows economic organizations to acquire agricultural land use rights of households and individuals (except for rice land paddy land, protection forest land or special-use forest land as stipulated in Article 191.2 Land Law 2013) and Article 169.1.e of Land Law 2013 allows economic organizations to acquire land use rights through receipt of contribution of land use rights as capital to create land fund production. However, there are a series of provisions in the 2013 Land Law that hinder the transfer and receipt of capital contribution by agricultural land use rights, specifically: in Article 133.1 of Land Law 2013 stipulates that if economic organization have a demand for agricultural, forestry, aquaculture or salt production, the State shall consider and lease land to implement investment projects; Article 60.3 of Land Law 2013 specifies that economic organizations belonging to the case of land lease under the provisions of Land Law 2013 which have received legal land use right transfers before the effective date of Land Law 2013, may continue using the land for the remaining land use duration without having to change to lease land; Article 60.4 of Land Law 2013 stipulates that an economic organization belonging to a land lease case of Land Law 2013 that has received transfer of land use right from households and individuals allocated by the State without collection of land use fees in order to implement an investment project on agricultural production before the effective date of the Land Law 2013, may continue to use the land for the remainder of the project without changing to renting land; Article 77.2 Decree No. 57/2018/ND-CP stipulates that enterprises with special agricultural projects are entitled to special investment incentives, investment incentives and encouragement on investment incentives, when receiving capital contributions by land use rights of household and individuals to form material areas, they will not have to switch to renting land for the areas of land which received capital contributions through land use rights.

Hence, with these regulations, even though the enterprise has acquired agricultural land use rights or received agricultural land use rights as contributed capital, the enterprise must continue to be considered by the State to lease land to that land. It is clear that this is a difficult task which causes additional costs for enterprises in accessing agricultural land and concentrating agricultural land with large areas for production.

Practically, in order to overcome this shortcoming, in recent years, in some localities of Vietnam, the government has rented land from the people and released agricultural land to the economic organizations or mobilized the people to authorize local governments to sign land lease contracts with enterprises, specifically:

In $\mathrm{Ha}$ Nam province, in order to attract investment in agricultural production, Ha Nam boldly hired land from the people (20 years) and then the province signed a contract for releasing land for enterprises with exactly the time renting and renting fee from people while the certificate of land use rights still be kept by farmer ... Ha Nam also piloted from the provincial budget to pay 
land rent to households during the land lease period of 20 years, after that the enterprise paid the land rent for the first 10 years immediately after signing the contract then paid the remaining land rent in the rest 10 years. After a pilot period, Ha Nam has accumulated 375.5 hectares; 02 high-tech agricultural zones in Ly Nhan district that went into operation with an area of 202.3 hectares ... (Hung The, 2018);

In Thai Binh province, "land accumulation in Thai Binh is carried out in the form of mobilizing people to authorize local governments to sign contracts with land leasing enterprises to invest in agricultural production for the duration of 20 years or more. By this mechanism, by the end of 2016, Thai Binh has concentrated and accumulated 9,914 hectares; in which, the area of land lease and transfer of land use rights is 3,292 hectares and concentrated linkage is 6,442 hectares. At present, there are 36 organizations and 343 individuals participating in concentrated implementation, land accumulation in two forms: land lease and transfer of land use rights" (Trung Thanh, 2017).

It can be considered as a creation to avoid the provisions of Land Law 2013 of localities in order to facilitate enterprises with agricultural land to implement investment projects. However, basically, this is a short-term solution, which complicates the relationship between people with agricultural land, enterprises in need of agricultural land and the State agencies. Simultaneously, this solution is only effective for some places with high consensus between the people and local authorities.

Secondly, the agricultural land use term is not suitable for the characteristics of agricultural production.

Although Land Law 2013 has increased the agricultural land use term by 50 years, this period is still relatively short for agricultural production. In order to recover the invested capital and make the profit for agricultural production, it takes longer than other kinds of production and business. Meanwhile, Article 126.2 of Land Law 2013 stipulates that the agricultural land use term is equal to land use term for service, commercial purposes, and non-agricultural production facilities (50 years), which is not suitable to the characteristics of agricultural production. In addition, according to Article 128.1 of Land Law 2013, agricultural land use term through the acquisition of land use rights and contribution of land use rights is even shorter because the agricultural land use term is the remaining term of the land use term before receiving the acquisition of land use rights. With a short term of agricultural land use, enterprises do not boldly invest large capital into agricultural production because of potential risks when they cannot continue to lease land from the State.

Thirdly, enterprises cannot capitalize on their own agricultural land to invest in agricultural production.

Although Article 174.2.d of Land Law 2013 allows enterprises to mortgage agricultural land use rights at credit institutions, in reality, enterprises cannot mortgage existing agricultural land use rights. Because credit institutions in Vietnam nowadays do not seem to accept mortgages on agricultural land but mainly take mortgages on residential land or land used for service, commercial purposes, and non-agricultural production facilities. The underlying cause of this situation is that agricultural land is being undervalued in the land price list issued by the State, specifically: "01 hectare of rice in the Mekong Delta region has the real value from 1-2 billion (Vietnam Dong). However, when determining the credit, farmers can only mortgage 200-300 million (Vietnam Dong) because the price of agricultural land is regulated by the Provincial-level People's Committee, only equals to $1 / 10$ of the actual value" (Thinh Le Duc, 2017).

Fourthly, about incentives and supports for foreign-invested economic organizations and enterprises.

In general, the preferential and support policies for agricultural production development in Vietnam are considered to be relatively low compared to many countries in the world, namely: "Developing agricultural policies can be assessed by the change in level of support calculated in \% PSE (Estimated support for producers as a part of the total revenue of farmers) and \% TSE (Estimate the total level of support as a part of GDP). In the period 2000-13, the support level is quite fluctuating without any clear long-term orientation. However, \% PSE remained positive for most of this period, indicating that producers generally received modest support. The level of support to producers is calculated according to the average \% PSE, reaches $7 \%$ in the years 2011- 
13; less than half of China and Indonesia, and significantly lower than the average of OECD at $18 \%$ \% (OECD, 2015).

Incentives and supports in accessing and using agricultural land that regulated by law for economic organizations are not out of this fact. Basically, incentives and supports that economic organizations and foreign-invested enterprises enjoy in accessing and using agricultural land are mainly exemption and reduction of agricultural land and water surface rent of the State. Previously, Decree No. 210/2013/ND-CP stipulated that enterprises which have agricultural projects with investment incentives were exempted from land and water surface rent for the first 15 years since the day the project was completed and went into operation; enterprises which have agricultural projects with encouraging investment were exempted from land and water surface rent for the first 11 years since the day the project is completed and went into operation. Currently, Decree No. 57/2018/ND-CP provides additional incentives and support for these cases in terms of reducing land and water surface rent, which are: $50 \%$ reduction of land and water surface rent in the next 7 years for enterprises which have agricultural projects with investment incentives; $50 \%$ reduction of land and water surface rent in the next 5 years for enterprises which have agricultural projects with encouraging investment. It is clear that these incentives are short-term and low. At the same time, in the practice of implementing policies to encourage enterprises to invest in agriculture under the provisions of Decree No. 210/2013/ND-CP, the biggest difficulty to support such enterprises is capital, which is still small, mainly depends on the capital from the central budget and has not get interested and implementation from the locality, thus it has not achieved high efficiency, specifically: "The localities which proposed support from central budget are mostly difficult localities, leading to the lack of reciprocal capital from the local budget, the 2016 plan for many localities without capital for the Program of agricultural reconstruction to implement policies to encourage enterprises. In 2017, the total central budget assigned to the localities is not separated into sectors and areas, thus the amount of capital allocated to implement Decree No. 210/2013/ND-CP is very little. The capital is transferred to localities but there is no support for enterprises in production under Decree 210; simultaneously, the local capital has not been allocated as stipulated in Article 17 Decree No. 210/2013/ND-CP which is from 2-5 \% for implementation" (Ministry of Planning and Investment, 2017).

From the above-analyzed contents, in order to create more advantageous conditions for enterprises to invest in agricultural production in Vietnam in the current period, Land Law 2013 needs to be modified at some issues:

Firstly, removing difficulties in accessing and concentrating agricultural land, in which Land Law 2013 needs to delete regulations that enterprises must re-lease agricultural land from the State after the acquisition of land use rights and contribution as a capital of land use rights.

Secondly, it's necessary to extend the term of agricultural land use or remove the land use term in Land Law 2013.

Thirdly, it is necessary to amend the provisions of Land Law 2013 on land prices, whereby the land price must be the actual land price in the market.

At the same time, the incentives and support of the State for enterprises with agricultural production need to be increased with more kind of incentives and support levels to create an attraction for enterprises to invest in agriculture. It is also necessary to supply regulations to enhance the responsibility of localities to implement incentives and support provided by law for enterprises, in which directly emphasizing the responsibility of the Chairman of People's Committee at all levels.

\section{Research result}

This study has clarified the content of the current legal regulations for enterprises using agricultural land as well as the reality of implementation of these regulations in Vietnam today. In particular, the provisions of Land Law 2013 are hindering enterprises to invest in agricultural production, which has been pointed out and proposed to be revised in this study.

\section{Conclusion}

The current Vietnamese law is to create favorable conditions with incentives and support for enterprises in accessing and using agricultural land so that they can invest in the agricultural sector. However, the participation of enterprises in the agricultural sector is very limited which makes the 
goal of comprehensive agricultural development towards modernization is difficult to accomplish in the future. This shows that the provisions of Land Law 2013 are not suitable for reality, making it difficult for enterprises to access and use agricultural land in a long-term and effective way. It is required to have new changes in order to attract enterprises to invest in agriculture.

\section{References}

Decree No. 210/2013/ND-CP - Decree No. 210/2013/ND-CP on incentive policies for enterprises investing in agriculture and rural areas, posted on the website of the Government. [Electronic resource]. URL: http://vanban.chinhphu.vn/portal/page/portal/chinhphu/ hethongvanban?class_id=1\&mode=detail\&document_id=171355

Decree No. 39/2018/ND-CP - Decree No. 39/2018/ND-CP on guidelines for the law on support for small and medium-sized enterprises, posted on the website of the Government. [Electronic resource]. URL: http://vanban.chinhphu.vn/portal/page/portal/chinhphu/ hethongvanban?class_id=1\&_page=1\&mode=detail\&document_id=193166

Decree No. $57 / 2018 /$ ND-CP - Decree No. $57 / 2018 / \overline{N D}-C P$ on incentive policies for enterprises investing in agriculture and rural areas, posted on the website of the Government. [Electronic resource]. URL: http://vanban.chinhphu.vn/portal/page/portal/chinhphu/hethong vanban?class_id=1\&mode=detail\&document_id=171355

Decree No. 61/2010/ND-CP - Decree No. 61/2010/ND-CP on incentive policies for enterprises investing in agriculture and rural areas, posted on the website of the Government. [Electronic resource]. URL: http://vanban.chinhphu.vn/portal/page/portal/chinhphu/hethong vanban?class_id $=1 \&$ mode $=$ detail\&document_id=95022\&category_id=0

Decree No.118/2015/ND-CP - Decree No.118/2015/ND detailing and guiding the implementation of a number of articles of the Investment Law, posted on the website of the Government. [Electronic resource]. URL: http://vanban.chinhphu.vn/portal/page/portal/ chinhphu/hethongvanban?class_id=1\&_page=1\&mode=detail\&document_id=182195

General Statistics Office - 2018 - General Statistics Office (2018). Report: Set of the main indicators that assess the level of enterprises development in the country and localities in 2017 and the period of 2010-2017, posted on the website of General Statistics Office date 13/10/2018. [Electronic resource]. URL: https://www.gso.gov.vn/Default.aspx?tabid=382\&ItemID=18970

General Statistics Office, 2017 - General Statistics Office (2017). Press release on the preliminary results of the 2017 Economic, posted on the website of General Statistics Office date 19/01/2018. [Electronic resource]. URL: https://www.gso.gov.vn/Default.aspx?tabid=382 \&ItemID $=18686$

General Statistics Office, 2018 - General Statistics Office (2018). Report: Set of the main indicators that assess the level of enterprises development in the country and localities in 2017 and the period of 2010-2017, posted on the website of General Statistics Office. [Electronic resource]. URL: https://www.gso.gov.vn/Default.aspx?tabid=382\&ItemID=18970

Hung The, 2018 - Hung The (2018). Locality rent land from people for 20 years and then lease it back to the enterprise, posted on the website of Dan Tri electronic newspaper date 30/10/2018. [Electronic resource]. URL: https://dantri.com.vn/kinh-doanh/dia-phuong-thue-datcua-dan-20-nam-roi-cho-doanh-nghiep-thue-lai-20181030120010815.htm

Luan Nguyen Thanh, 2018a - Luan Nguyen Thanh (2018). Provision of agricultural land law in Vietnam - reality, and petition for changes. Russian Journal of Legal Studies, 2018, Vol. (5), Is. 1. pp. 40-48.

Luan Nguyen Thanh, 2018b - Luan Nguyen Thanh (2018). Law in recovery of agricultural land to develop socio-economic for national and public interest of Vietnam nowadays: reality and petition for changes. Russian Journal of Comparative Law, 2018, Vol (5), Is. 2. pp. 117-126.

Ministry of Natural Resources and Environment, 2017 - Ministry of Natural Resources and Environment (2017). Decision number 2311/QD-BTNM on Approving and announcing the results of land area statistics in 2016, date 28/9/2017.

Ministry of Planning and Investment, 2017 - Ministry of Planning and Investment (2017). Report on the implementation of policies to encourage enterprises to invest in agriculture and rural areas, 3/2017, P. 10. 
Nguyễn Quốc Nghi 2014 - Nguyễn Quốc Nghi (2014). Market risks in agricultural production of households in the Mekong Delta. Scientific Journal of Can Tho University, No. 33/2014, P. 39.

OECD, 2015 - OECD (2015). Report on review of agriculture and food of OECD: Agricultural policy in Vietnam, PH. PECD, Paris, 3/2015, p. 35.

Tam Thanh, (2018), What should be done to make FDI "pour" more into agriculture?, Published on the Electronic Journal of Agricultural Communication date 03/8/2018. [Electronic resource]. URL: http://kinhtenongthon.vn/lam-gi-de-fdi-do-vao-nong-nghiep-nhieu-honpost21174.html

Thinh Le Duc, 2017 - Thinh Le Duc (2017). Speaking at the Conference "Spring Agriculture Forum 2017", held in Hanoi, date 28/3/2017.

Trung Thanh, 2017 - Trung Thanh (2017). Piloting the mechanism of land accumulation: Ensuring harmonization of benefits, Posting on Bnews electronic Newspaper. [Electronic resource]. URL: https://bnews.vn/thi-diem-co-che-tich-tu-dat-dai-bao-dam-hai-hoa-loi-ich/61914.html

Vietnamese Enterprises Law Act, 2014 - Vietnamese Enterprises Law Act, 2014 posted on the website of the Ministry of Justice. [Electronic resource]. URL: http://www.moj.gov.vn/vbpq/lists/vn\%20bn\%20php\%2olut/view_detail.aspx?itemid=30314

Vietnamese Investment Law Act, 2014 - Vietnamese Investment Law Act, 2014 posted on the website of the Ministry of Justice. [Electronic resource]. URL: http://www.moj.gov.vn/vbpq/lists/ vn\%20bn\%2ophp\%2olut/view_detail.aspx?itemid=30315

Vietnamese Land Law Act, 2013 - Vietnamese Land Law Act, 2013 posted on the website of the Ministry of Justice. [Electronic resource]. URL: http://www.moj.gov.vn/vbpq/lists/vn\%20bn\% 20php\%2olut/view_detail.aspx?itemid=28824 